\title{
Detection of short tandem repeats at 5 loci and amelogenin with cell-free fetal DNA as a specimen in the development of prenatal paternity diagnostic tests
}

\author{
Agung Sosiawan ${ }^{1 *}$, Dadik Raharjo ${ }^{2}$, Indah Nuraini ${ }^{3}$, Nadia Kartikasari ${ }^{1}$, Alexander Patera Nugraha ${ }^{1}$ \\ and Muhammad Dimas Aditya Ari ${ }^{1}$
}

\begin{abstract}
Introduction: A prenatal paternity test is one widely-used method of determining the paternity of an unborn child. Such tests using chorionic villus or amniocentesis may increase the risk of harm to both mother and foetus. In the present day, a prenatal paternity test using circulating cell-free fetal Deoxyribonucleic Acid (DNA) is one alternative method due to it being non-invasive and safe for both mother and foetus.

Aim: The aim of this study is to detect Short Tandem Repeat (STR) at 5 Loci (VWA, TH01, D13S317, D18S51, and D21S11) and amelogenin genes in circulating cell-free fetal DNA in paternity tests.

Materials and methods: Forty-one samples of maternal blood were obtained from pregnant woman. Circulating free fetal DNA was subsequently extracted. A paternity test was conducted using an STR test at loci VWA, TH01, D13S317, D18S51, D21S11 in circulating free fetal DNA. An analysis of the paternity test between loci $>200$ bp and $<200$ bp was also conducted to establish the sensitivity of the test.
\end{abstract}

Results: There was a significant difference between maternal blood DNA and circulating cell-free fetal DNA ( $p=0.000$ D13S317; $p=0.000$ D21S11; $p=0.000$ D18S51; $p=0.000$ vWA; $p=0.000$ TH01; and $p=0.000$ amelogenin genes). The locus $<200 \mathrm{bp}$ also had a higher sensitivity than locus $>200 \mathrm{bp}$.

Conclusion: Circulating free fetal DNA can be used as an alternative sample for prenatal paternity tests because of its similarity with maternal DNA.

Keywords: Early detection, Circulating free fetal DNA, Non-invasive technique, Prenatal paternity test

\section{Introduction}

A prenatal paternity test is one popular method of determining the paternity of an unborn child which requires direct chorionic villus or amniotic fluid sampling via amniocentesis (Guo et al. 2012; Ryan et al. 2013). Amniocentesis carries a 1 in 300 to 1 in 500 risk of miscarriage and very limited risk of other complications (Seeds 2004; Elchalal et al. 2004). Chorionic villus sampling carries a similar risk of miscarriage and a 1 in 3000 risk of fetal limb reduction defects, especially when performed within the first 10 weeks of gestation

\footnotetext{
* Correspondence: agung-s@fkg.unair.ac.id

${ }^{1}$ Faculty of Dental Medicine, Universitas Airlangga, Jl. Mayjend. Prof. Dr. Moestopo 47, Surabaya 60132, Indonesia

Full list of author information is available at the end of the article
}

(Brambati et al. 1992). Due to this risk, a non-invasive method of carrying out prenatal paternity tests has been developed.

Circulating cell-free fetal DNA diagnostic technique is a non-invasive technique which uses circulating cell-free fetal DNA contained in maternal blood at the 8-week stage of pregnancy or later (Guo et al. 2012). This technique was intended to meet the "challenge" of developing diagnostic methods in the field of gynecology obstetrics for prenatal cases mainly related to genetic disorders which have been of concern in the foeto-maternal field. Although this technique was first reported more than decade ago, the development of and reporting on this study remains limited (Ryan et al. 2013). 
The use of fetal cell-free DNA in obstetrics gynecology and the urgent need for samples based on circulating cell-free fetal DNA in forensic cases in the future is inevitable. Prenatal paternity tests may successfully address the complexity of unborn child identification in abortus provocatus or rape cases. The presence of residual cell-free fetal matter derived from previous pregnancies and the technical challenges associated with the amount of fetal DNA in early pregnancy which is usually less than $20 \%$ of the total DNA circulating freely are investigated here (Barrett et al. 2011; Lo et al. 1998). The aim of this study is to detect paternity tests using Short Tandem Repeat (STR) at 5 Loci (vWA, TH01, D13S317, D18S51, and D21S11) and amelogenin genes gender determination in cell-free fetal DNA.

\section{Materials and methods}

Peripheral blood was collected from 41 women during the first, second and third trimesters of their pregnancy. This research has been approved with ethical clearance from the Committee of Ethical Clearance of Health Research, Faculty of Dental Medicine, Universitas Airlangga (No. 014/ HRECC.FODM/II/2017). Participating volunteers signed a consent form and their right to privacy was consistently observed.

Plasma was obtained by centrifugation of maternal blood samples contained in $2 \mathrm{ml}$ Eppendorf tubes at $3000 \mathrm{rpm}$ for 10 min. Plasma was obtained by means of careful separation with a buffycoat before being re-centrifugated at $6000 \mathrm{rpm}$ for $10 \mathrm{~min}$. DNA extraction was performed by means of an organic method using DNAzol (Invitrogen, ThermoFisher Scientific, Waltham, MA, USA). DNA concentration and purity were measured in a sample that had been previously extracted with a UV-spectrophotometer (Shimidzu UV-16, Kyoto, Japan). DNA amplification was performed with PCRSTR (Polymerase Chain Reactions-Short Tandem Repeat) at five loci of CODIS (Combined DNA Index System) to the FBI standard (Federal Bureau of Investigation) D13S317, vWA, TH01, D18S51, D21S11 and gene amelogenin for gender determination (cat. K562, GoTaq ${ }^{\circ}$ Green Master Mix, Promega Corp, Madison, USA). The results were obtained through PCR-STR and subsequently analyzed to determine the pattern of "exclusion-inclusion" between the sample and comparison groups. Data analyses were visualized using Gel Poliacrylamide 6\% gel (cat. K562, GoTaq ${ }^{\circ}$, Green Master Mix, Promega Corp, Madison, USA) and statistical methods relating to independent samples on SPSS 17.0 for Windows with $p<0.01$.

\section{Results}

DNA was extracted from the peripheral blood of 41 pregnant women. Circulating cell-free fetal DNA and maternal DNA were separated and their concentration and purity measured. The comparison of DNA concentration from circulating cell-free fetal DNA and maternal DNA can be seen in Fig. 1.

The mean percentage (\%) of fetal DNA contained in maternal DNA was then calculated at $16.24 \pm 1.67 \%$. The mean score was subsequently subjected to statistical analysis and the results compared with the successful analysis of loci D13S317, D18S51, D21S11, vWA, TH01 and amelogenin. The results are shown in Table 1.

Table 1 showed the PCR-STR at loci D13S317, D18S51, D21S11, vWA, TH01 and the amelogenin derived from circulating cell-free fetal DNA inherited from parental allele. This result meant that a technical analysis of the results of an STR examination on circulating cell-free fetal DNA could be conducted. Table 2 shows a comparison between the loci $>200 \mathrm{bp}$ and $<200 \mathrm{bp}$ in length. There was a significant difference between the loci above and below 200 bp in length. Locus < 200 bp has a higher sensitivity than locus $>200 \mathrm{bp}$.

\section{Discussion}

Extracting maternal plasma during pregnancy for the purposes of molecular analysis has become increasingly common in recent times. The identification of fetal DNA in the maternal bloodstream represents a promising new hope for the development of non-invasive, prenatal diagnostic techniques which still encounter many problems in their application (Lo et al. 1998). The use of circulating cell-free fetal DNA found in maternal plasma enables forensic examination to be performed in paternity cases (Rong et al. 2012; Sarasola et al. 2006). Detection by means of circulating cellfree fetal DNA is capable of determining the gender of the foetus after 8 weeks of pregnancy (Colmant et al. 2013).

In this study, the respective DNA concentrations of circulating cell-free fetal DNA and maternal blood were compared, with significant differences being identified. This percentage indicates that the quantity of DNA derived from circulating cell-free fetal is high. DNA derived from circulating cell-free fetal DNA can be used as a specimen for the purposes of DNA examination by means of PCR method. This is due to the requirement that the volume of DNA specimens used in forensic DNA profiling must be at least $20 \mathrm{ng} / \mathrm{ml}$ (Notosoehardjo 1999).

The average purity of both maternal blood DNA or circulating cell-free fetal DNA is 1.79 , allowing DNA to be used in PCR amplification (Muladno 2002). DNA purity can be classified as high if it falls within the range of 1.8-2.0. This study shows DNA purity to fall outside that range possibly because protein contamination might have occurred during the isolation of the DNA sample. The purity level of forensic DNA samples does not pose a significant problem if it remains above 1 . The purity of DNA ranging from 1 to 2 for forensic DNA examination can still be used for DNA typing using PCR (Notosoehardjo 1999; Muladno 2002). 


\section{DNA Concentration}

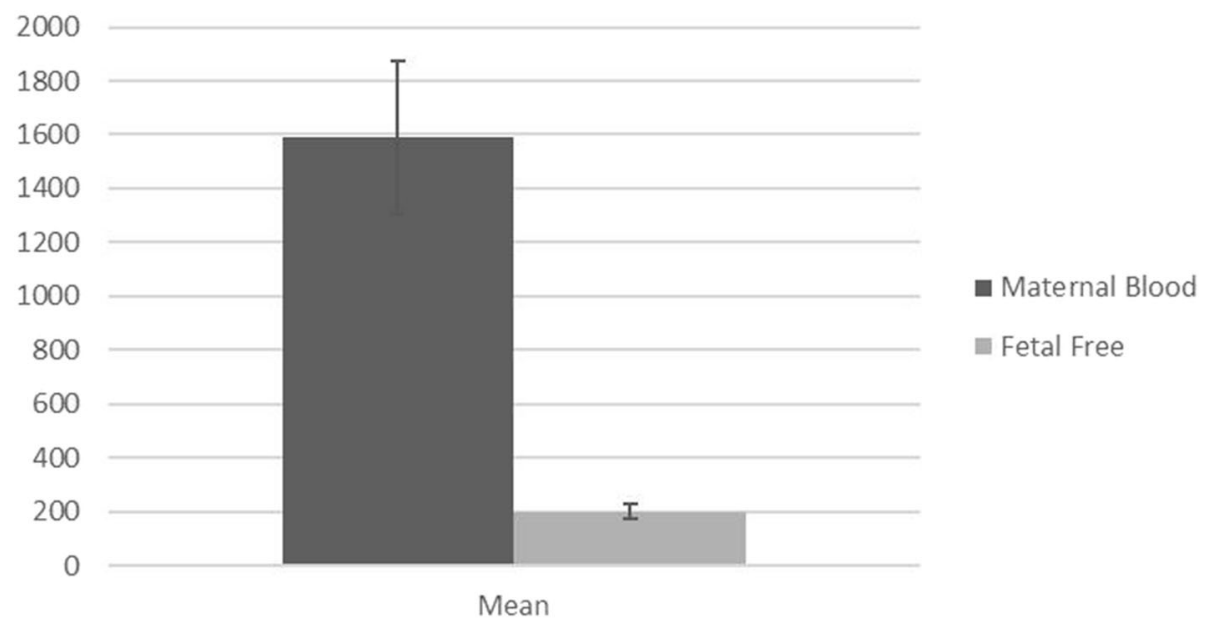

Fig. 1 Comparison of DNA concentration from circulating cell-free fetal DNA and maternal blood using T-test. There was a significant difference between circulating cell-free fetal DNA and maternal blood with $p=0.000(p<0.01)$

PCR is a sensitive method of DNA amplification. In forensic science, particularly the field of DNA typing, this method is also applied due to its ability to amplify small quantities of DNA (Kashyap et al. 2004). However, the limited amount of target DNA in certain circumstances does not affect the success of PCR. This research used several STR loci, such as loci vWA, TH01, D132317, D18S51, and D21S11, in addition to amelogenin genes for gender examination. It can be concluded from this study that the detection of forensic DNA of a length less than $400 \mathrm{bp}$ was successful. The possibility of DNA fingerprinting using cell-free fetal DNA specimens was also confirmed. Nevertheless, the cell-free fetal DNA contained in certain samples failed the DNA fingerprinting process for one sample of circulating cellfree fetal DNA during the examination of loci D18S51 and D21S11. This occurrence might have been due to the fact that circulating cell-free fetal DNA in maternal plasma is, in general, shorter than maternal DNA (Rong et al. 2012). Failures in identification in loci D18S51 and D21S11 could also have been caused by problems associated with the amplification process or the occurrence of "false negative" results in the DNA multiplication process.

Table 1 Comparison of percentage fetal DNA in loci analysis using Willcoxon Signed Rank test

\begin{tabular}{lclllll}
\hline & $p$ value & & & & & \\
\cline { 2 - 7 } & D13S317 & D18S51 & D21S11 & vWA & TH01 & amelogenin \\
\hline $\begin{array}{l}\text { Success of } \\
\text { Paternity Test } \\
\text { using STR } \\
\text { analysis }\end{array}$ & $0.000^{*}$ & $0.000^{*}$ & $0.000^{*}$ & $0.000^{*}$ & $0.000^{*}$ & $0.000^{*}$ \\
\hline
\end{tabular}

*was significant statistically $(p<0.01)$
These were possibly caused by the quality of circulating cell-free fetal DNA from the foetus or of fetal origin in the maternal plasma. Hence, the research samples in loci D18S51 and D21S11 were not successfully identified.

This research provided promising results for the use of circulating cell-free fetal DNA as a specimen of paternity examination in loci vWA, TH01, D13S317, D18S51, D21S11 and gender examination using amelogenin genes with non-invasive techniques. The study conducted by Wegner et al. (2009) was not able to successfully amplify autosomal fetal alleles from maternal plasma. Amelogenin was the only locus that was reliably amplified by the use of AmpFLSTR. Amelogenin revealed only fetal gender, while the amplification of other autosomal loci was sporadic and insufficient for reliable paternity testing (Wagner et al. 2009). The study reported here confirmed the success of this research as being relatively high: approximately 100\% for loci of vWA, TH01, D13S317, 100\% for amelogenin genes, $90 \%$ for loci D18251 and D21S11, giving an average success rate of $96 \%$. This rate is relatively high considering the circulating cell-free fetal DNA. The results of this study are in accordance with those of a study conducted by Jiang et al. (Jiang et al. 2016) which proved that maternal plasma DNA sequencing-based technology is feasible and accurate in determining paternity, possibly providing an alternative

Table 2 Comparison in success analysis of loci length above and below 200 bp using Willcoxon Signed Rank test

$p$ value

locus $<200$ bp

locus $>200$ bp

$0.000^{*}$

${ }^{*}$ was significant statistically $(p<0.01)$ 
for forensic application in the future. This method could also be a unique means of detecting DNA loci with an average length of $100 \mathrm{bp}$ (Rong et al. 2012).

According to a previous study conducted by Rong et al. (Rong et al. 2012), the Loci of vWA, TH01, D13S317, D18251, D21S11 and gender examination using amelogenin feature relatively long-base pairs which facilitate targeted locus examination. Locus D13S317 has a length of 169-201 bp, D18S51 is 290-266 bp in length, D21S11 is 203-259 bp in length, VWA is $127-167$ bp in length, TH01 is 179-203 in length, while amelogenin genes are 106-112 bp in length. Long-base pair loci can be employed as paternity examination loci using cell-free fetal DNA as the examination material, although fetal cfDNA has reportedly also played this role for at least a decade (Ryan et al. 2013).

Paternity tests can be carried out using circulating cell-free fetal DNA (Ryan et al. 2013). There are three main reasons why cell-free DNA can be used for the purposes of paternity tests. The first is that circulating cell-free fetal DNA is derived from a foetus circulating in maternal blood even though at low concentration levels. Cell-free fetal DNA is essentially the DNA molecules outside the maternal DNA derived from the foetus whose use in DNA paternity tests has been sanctioned. Circulating cell-free fetal DNA inherits half of the maternal genetic sequences, thereby enabling it to be distinguished from the mother's DNA (Wright 2009). This study could prove that there is allele conformity at loci D13S317, D18S51, D21S11, VWA, TH01 between fetal alleles and those derived from a mother and father in accordance with Mendel's hereditary law.

Regarding the amount of human DNA, there are several different opinions about the minimum amount required for DNA analysis in forensic science. The minimum required amount for DNA typing in forensics ranges from 0.1 to $50 \mathrm{ng}$ (Mandrekar et al. 2001). Another study showed that the DNA templates recommended for use in DNA typing contain 100-1000 ng (Kline et al. 2003). Meanwhile, a further piece of research confirmed that the minimum amounts of DNA used in forensic science are $50 \mathrm{ng}$ and $20 \mathrm{ng}$ respectively (Notosoehardjo 1999). STR method-based DNA testing could produce reliable results at minimum DNA concentrations of 0.5-2.5 ng (Kline et al. 2003). Although there are different opinions about the minimum amount of DNA that can be used in DNA analysis, in principle, the required amount in DNA forensic analysis depends on the necessity for and type of examination conducted. The Restriction Fragment Length Polymorphism (RFLP)-based forensic DNA examination requires relatively large amounts of about 100-1000 ng (Kline et al. 2003). The large amount of DNA used for RFLP tests is far from fresh, but the large amount of DNA is aimed to increase the likelihood of success in the management of DNA profiling. The STR test only requires a minimum DNA concentration ranging from $0.25-2 \mathrm{ng}$ (Andelinović et al. 2005).

In addition, the amount or concentration of DNA for PCR-based DNA examination needs to be adequate, while its degraded condition should be at a minimum. Seriously degraded DNA has the potential to prevent primer attachment or aneling on the target DNA. Therefore, the quality of DNA represents a fundamental factor in the successful use of the PCR method (Yamada et al. 2002). The sensitivity of PCR is dependent on the function of the DNA's cycle, amount and integrity. Low DNA levels in forensic investigations may sample up to a certain level that will not significantly affect the success of DNA profiling in forensic science, especially in STR tests. This is due to the amount of DNA required for the successful conducting of STR tests tending to be the lowest compared to other DNA-based tests. Consequently, the risk of failure of DNA amplification with this technique is relatively small (Chung et al. 2004).

\section{Conclusion}

The fraction of DNA derived from circulating cell-free fetal DNA is low in quantity. Nevertheless, the circulating cell-free fetal DNA or ccffDNA can be used as a DNA specimen by STR-PCR using loci D13S317, D18S51 and D21S11, VWA, TH01 and amelogenin genes for the purposes of paternity detection.

\section{Abbreviations \\ bp: Base pair(s); ccffDNA: Circulating cell-free fetal DNA; cfDNA: Cell free DNA; CODIS: Combined DNA Index System; DNA: Deoxyribonucleic Acid; FBI: Federal Bureau of Investigation; PCR: Polymerase Chain Reactions; PCR- STR: Polymerase Chain Reactions-Short Tandem Repeat; RFLP: Restriction Fragment Length Polymorphism; STR: Short Tandem Repeat}

\section{Acknowledgements}

The authors would like to thank the Universitas Airlangga (UNAIR), Faculty of Medicine and Faculty Dental Medicine, Human Genetic and Forensic Laboratory, Institute for Tropical Diseases, Universitas Airlangga, Surabaya, Indonesia.

\section{Funding}

This research has been funded by Penelitian Unggulan Pengguruan Tinggi Negeri (PUPTN) Ministry of Research and Higher Education Indonesia with award number and Grant Recipient was Agung Sosiawan, Ph.D.

\section{Authors' contributions}

Conception and design of the study: AS, DR, IN. Acquisition of data: AS, DR, IN. Drafting the manuscript: NK, APN, MDAA. Revising the manuscript critically for important intellectual content: AS, NK, APN, MSAA. All authors read and approved the final manuscript.

\section{Competing interests}

The authors declare that they have no competing interests.

\section{Publisher's Note}

Springer Nature remains neutral with regard to jurisdictional claims in published maps and institutional affiliations.

\section{Author details}

${ }^{1}$ Faculty of Dental Medicine, Universitas Airlangga, Jl. Mayjend. Prof. Dr. Moestopo 47, Surabaya 60132, Indonesia. ${ }^{2}$ Public Health Departement, 
Faculty of Veterinary, Universitas Airlangga, Kampus C UNAIR Mulyorejo, Surabaya 60132, Indonesia. ${ }^{3}$ Human Genetic and Forensic Laboratory, Institute for Tropical Diseases, Universitas Airlangga, Kampus C UNAIR Mulyorejo, Surabaya 60132, Indonesia.

Received: 2 June 2017 Accepted: 23 January 2018

Published online: 02 February 2018

\section{References}

Andelinović S, Sutlović D, Erceg Ivkosić l et al (2005) Twelve-year experience in identification of skeletal remains from mass graves. Croat Med J 46(4):530-539

Barrett AN, Zimmermann BG, Wang D, Holloway A, Chitty LS (2011) Implementing prenatal diagnosis based on cell-free fetal DNA: accurate identification of factors affecting fetal DNA yield. PLoS One 6(10). https://doi. org/10.1371/journal.pone.0025202

Brambati B, Simoni G, Travi M et al (1992) Genetic diagnosis by chorionic villus sampling before 8 gestational weeks: efficiency, reliability, and risks on 317 completed pregnancies. Prenat Diagn 12(10):789-799. https://doi.org/10. 1002/pd.1970121004

Chung DT, Drábek J, Opel KL, Butler JM, BR MC (2004) A study on the effects of degradation and template concentration on the amplification efficiency of the STR Miniplex primer sets. J Forensic Sci 49(4):733-740. https://doi.org/10. 1520/JFS2003269

Colmant C, Morin-Surroca M, Fuchs F, Fernandez H, Senat MV (2013) Non-invasive prenatal testing for fetal sex determination: is ultrasound still relevant? Eur J Obstet Gynecol Reprod Biol 171(2):197-204. https://doi.org/10.1016/j.ejogrb.2013.09.005

Elchalal U, Ben SI, Peleg D, Schenker JG (2004) Maternal mortality following diagnostic 2nd-trimester amniocentesis. Fetal Diagn Ther 19(2):195-198. https://doi.org/10.1159/000075150

Guo X, Bayliss P, Damewood M et al (2012) A noninvasive test to determine paternity in pregnancy. N Engl J Med 366(18):1743-1745. https://doi.org/10. 1056/NEJMC1113044

Jiang H, Xie Y, Li X et al (2016) Noninvasive prenatal paternity testing (NIPAT) through maternal plasma DNA sequencing: a pilot study. PLoS One 11(9). https://doi.org/10.1371/journal.pone.0159385

Kashyap VK, Sitalaximi T, Chattopadhyay P, Trivedi R (2004) DNA profiling Technologies in Forensic Analysis. Int J Hum Genet 4(1):11-30

Kline MC, Duewer DL, Butler JM (2003) Biotech SRMs designed for the rapidly evolving forensic DNA and human identity testing communities. In: National Conference of standards laboratories international. In

Lo YM, Tein MS, Lau TK et al (1998) Quantitative analysis of fetal DNA in maternal plasma and serum: implications for noninvasive prenatal diagnosis. Am J Hum Genet 62(4):768-775. https://doi.org/10.1086/301800

Mandrekar MN, Erickson AM, Kopp K et al (2001) Development of a human DNA quantitation system. Croat Med J. 42:336-339

Muladno (2002) Seputar Teknologi Rekayasa Genetika [around genetics engineering technology], 1st edn. Pustaka Wirausaha Muda, Bogor

Notosoehardjo I. Penentuan jenis kelamin berdasarkan Pemeriksaan DNA dan Antropometri tulang [Determining sex based on DNA tests and bone Anthropometry]. 1999

Rong Y1, Gao J, Jiang XZF (2012) Multiplex PCR for 17 Y-chromosome specific short tandem repeats (STR) to enhance the reliability of fetal sex determination in maternal plasma. Int J Mol Sci 13(5):5972-5981. https://doi.org/10.3390/ijms13055972

Ryan A, Baner J, Demko Z et al (2013) Informatics-based, highly accurate, noninvasive prenatal paternity testing. Genet Med 15(6):473-477. https://doi. org/10.1038/gim.2012.155

Sarasola E, Rodrıguez-Alarcon J, Martin-Vargas L, Melcho JC, Martinez de Pancorbo M (2006) Fetal sex determination from maternal plasma by nested PCR of the amelogenin gene. Int Congr Ser 1288:691-693

Seeds JW (2004) Diagnostic mid trimester amniocentesis: how safe? In: American journal of obstetrics and gynecology. Vol 191, pp 608-616. https://doi.org/10 1016/j.ajog.2004.05.078

Wagner J, Dzijan S, Marjanović D, Lauc G (2009) Non-invasive prenatal paternity testing from maternal blood. Int J Legal Med 123(1):75-79. https://doi.org/10. 1007/s00414-008-0292-9

Wright C (2009) Cell-free fetal nucleic acids for non-invasive prenatal diagnosis report of the UK expert working group. Management 469(January):289-291

Yamada Y, Makimura K, Merhendi $\mathrm{H}$ et al (2002) Comparison of different methods for extraction of mitochondrial DNA from human pathogenic yeasts. Japanese J Infect Dis 55(4):122-125

\section{Submit your manuscript to a SpringerOpen ${ }^{\circ}$ journal and benefit from:}

- Convenient online submission

- Rigorous peer review

- Open access: articles freely available online

- High visibility within the field

- Retaining the copyright to your article

Submit your next manuscript at $\boldsymbol{\nabla}$ springeropen.com 